\title{
MONITORING VEGETATION COVER CHANGE USING VEGETATION INDICES IN TANGBO RIVER, BARANGAY TANGBO, SAMBOAN
}

\author{
Jireh Jasmin S. Yang ${ }^{1}$, Florencio P. Campomanes V' ${ }^{1}$, Chito L. Patino ${ }^{1}$, and Mary Joyce L. Flores ${ }^{1,2}$ \\ ${ }^{1}$ University of the Philippines Cebu Center for Environmental Informatics, Lahug, Cebu City, 6000 Philippines, \\ Email: jsyang@up.edu.ph \\ ${ }^{2}$ University of the Philippines Cebu, Lahug, Cebu City, 6000, Philippines
}

\section{Commission IV}

KEY WORDS: NDVI, EVI, NDMI, TCB, TCG, TCW, Riparian Vegetation, Tourism, Aguinid Falls

\begin{abstract}
:
Tangbo River is an important resource in Cebu's southern town of Samboan for being the site of Aguinid Falls, a known tourist destination. Monitoring the changes in the river's riparian vegetation is important since it has impacts on its ecological role of helping maintain biodiversity and river water quality. This study aims to detect vegetation index changes along the Tangbo River corridor using three vegetation indices: NDVI, EVI, NDMI, and Tasseled Cap indices, specifically for the years 1998, 2004, 2009, 2016, and 2019. It also aims to monitor the changes in NDVI and EVI values alongside tourism arrivals in Aguinid in 2018.
\end{abstract}

Cloudless Landsat 5 (1998, 2004, 2009, and 2016) and Landsat 8 (2019) imagery were selected. Thirty reference points were plotted along the river with a 30-m distance between each point. Vegetation Indices (VI) and Tasseled Cap values were generated using data from these points and were compared for each selected year. NDVI and EVI values from the same reference points used in Landsat were generated from selected cloudless months of 2018 Planetscope imagery. Inbound tourist records were acquired from the tourism office of Samboan and the tourism arrivals for the year 2018 was then graphed with the Planetscope VI values for better visualization.

Landsat imagery showed that there was a general upward trend in the vegetation indices from 1998 to 2019. Tasseled Cap Greenness and Wetness showed an increase in values from 1998 - 2019 while Tasseled Cap Brightness showed the opposite. Results from Planetscope data for the year 2018 showed that there was an inverse pattern between NDVI and tourism arrivals. Tourism arrivals peaked during the months of April and May based on annual records, while VI values dropped. On the other hand, both VI values peaked towards the last quarter of the year while tourist numbers dropped. This suggests that the pattern of VI values and tourism arrivals seemed to be influenced by seasonal changes rather than with each other. Findings from the study shows that further data collection is required to be able to establish a relationship between tourism and vegetation index values.

\section{INTRODUCTION}

\subsection{Background of the study}

Tourism creates a sharing of knowledge between communities to promote a better understanding of cultures and the environment. It has become one of the sectors of the economy that developing countries have relied on since it has created more employment opportunities for locals (Dritsakis and Agorastos, 1999). A study on tourism sustainability shows that it is important to consider the effectiveness of tourism economy-wise, society-wise and environmental-wise (Spilanis and Glyptou, 2012).

Tourists continuously seek a more organic approach to attractions. Ecotourism, a subsector of tourism, involves visiting a more natural environment, as tourists want to be more environmentally aware, to seek adventure, or to appreciate culture that is foreign to them (Fennell, 2003).

The Philippines has seen a steady increase in its GDP, due in part to the tourism boom in the country (Business World, 2018). Ecotourism and adventure tourism have been strongly endorsed by the Philippine government because of how easily available these destinations are (Gatdula, 2018). The province of Cebu is one of the country's top contributors to tourism influx in the Philippines, specifically the ecotourism experiences that the island offers (Buslon-Sia et al., 2019). One of the province's municipalities, Samboan, boasts a number of natural tourist destinations, in both its mountainous and coastal regions, thus becoming one of the most visited destinations in Cebu (I. Gamallo, personal communication, July 3, 2019). Arguably the most known of its' attractions is Aguinid Falls, in Tangbo River, which has seen a steady flow of visitors since its opening to the public in 2013. Three years later, the site experienced a boom in tourism when it won an award for being the best ecotourism experience in the province which heightened interest around the area (Tizon, 2019).

Recently however, the municipality announced the temporary closure of the site. This was done to allow the river to recover from both natural and anthropogenic impacts caused by the El Niño and the tourism influx (Tizon, 2019). This event was one in a series of temporary closures of environmental tourist attractions which began with Boracay last year, in an attempt to rehabilitate the popular island (Yang, 2019).

While the rise of tourism in the Philippines has had a positive impact on its economy, great care must still be placed on the management of these natural destinations because they have been found to be highly sensitive to even the slightest influence (Alampay, 2005). Several countries in the past have adopted the ecotourism approach with varied results. One outcome common to the countries that have seen high numbers of guests is the endangerment or extinction of species in the said areas (Honey, 2008). 
Monitoring the riparian vegetation along Tangbo River is important since it is an area which receives a high number of tourists daily, with only a few days in the year set for cleanups save for its extended closure last June to July (I. Gamallo, phone communication, September 13, 2019). Riparian vegetation plays an important role in the ecosystem. It promotes biodiversity, serving as a bridge between the terrestrial and aquatic environment (Toribio et al., 2014). It also helps in maintaining the water chemistry of a river by taking in nutrients from the water, providing detritus for the soil, and altering the flow of water to stabilizing the riverbanks, thereby preventing erosion (Dosskey et al, 2010).

There are disturbances and stressors that may affect riparian vegetation. Disturbances are natural events, such as landslide, erosion, or flood. Stressors are anthropogenic influences, some of which are land use change, a decline in habitat quality, climate change, and invasive species (Stella and Bendix, 2019).

The need for sustainable tourism arises not just because it is practical but also because it encourages people from all walks of life to be more environmentally aware. Monitoring of the natural environment, careful planning, policymaking and most importantly the cooperation of the consumers all makes it possible to be able to create a sustainable tourist destination (Kiper, 2013).

One of the ways that can be used to monitor the riparian vegetation of the river are Vegetation Indices (VI) and Tasseled Cap indices. These may allow people to detect changes in vegetation cover through the use of unmanned aerial vehicles recording satellite images over a long period of time. It is an indirect method which uses data from visible and non-visible spectra reflected by plants to calculate vegetation health using specific mathematical equations (Xue, Su, 2017). Selection of appropriate indices may depend on which spectra the index uses as well as what variables it can eliminate (Jafari, Lewis, Ostendorf, 2007).

Vegetation indices are found to be influenced by climate (Perez and Comiso, 2014). Rainfall is shown to have a significant effect on vegetation index values through time (Liu et al., 2015). Phenomena such as the El Niño Southern Oscillation are also shown to affect vegetation cover as well (Patel et al., 2007). These indices are most commonly utilized in agriculture, such as in predicting and monitoring drought (Perez et al., 2016).

Results of the assessment of the changes in Tangbo River's riparan vegetation indices through time could contribute to the development of more improved tourism management practices and environmental maintenance.

\subsection{Objectives}

The study aims to monitor vegetation index changes along the Tangbo River Corridor, using three (3) vegetation indices: Normalized Difference Vegetation Index (NDVI), Enhanced Vegetation Index (EVI), Normalized Difference Moisture Index (NDMI), and three (3) Tasseled Cap indices: Brightness (b), Greenness (g) and Wetness (w).

Specifically, the study aims to monitor the trend of each vegetation index from 1998 to 2019, using cloudless Landsat 5 (1998, 2004, 2009, and 2016) and Landsat 8 (2019) imagery. It also aims to monitor the changes in NDVI and EVI along with inbound tourist records for the year 2018 using cloudless Planetscope imagery.

\section{METHODOLOGY}

\subsection{Study Area}

Tangbo River lies in Barangay Tangbo, Samboan in the southwestern region of Cebu Province. The river is commonly known to host the location of Aguinid Falls, a popular tourist destination (Buslon-Sia et al., 2019). Figure 1 shows the map of Tangbo River in the Municipality of Samboan, Cebu.

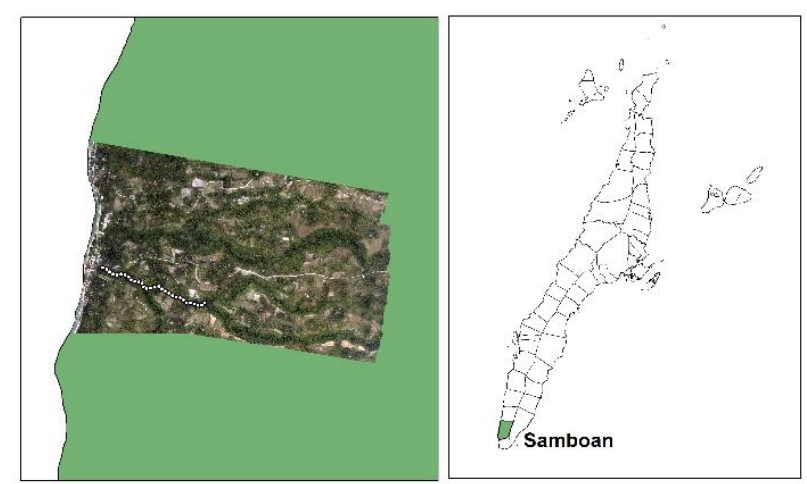

Figure 1. Location map of Tangbo River, Samboan, Cebu $\left(9^{\circ} 30^{\prime} 27^{\prime \prime} \mathrm{N}, 123^{\circ} 18^{\prime} 42.48^{\prime \prime} \mathrm{E}\right)$

\subsection{Data Sources}

\subsubsection{Satellite Imagery}

Satellite imagery were downloaded from the United States Geological Survey and Planetscope website. Table 1 shows the details of the satellite imagery which were collected for the study:

Table 1. Satellite imagery details collected from 1998 to 2019

\begin{tabular}{|c|c|c|c|c|}
\hline Satellite & $\begin{array}{c}\text { Date } \\
\text { Acquired }\end{array}$ & $\begin{array}{c}\text { Spatial } \\
\text { Resolution }\end{array}$ & $\begin{array}{c}\text { Temporal } \\
\text { Resolution }\end{array}$ & Bands \\
\hline $\begin{array}{c}\text { Landsat } \\
5\end{array}$ & 19980504 & $30 \mathrm{~m}$ & 16 days & 7 \\
& 20040214 & & & \\
& 20090619 & & & \\
Landsat & 20160130 & & & 11 \\
8 & 20190207 & & & \\
\hline Planet & 20180210 & $3 \mathrm{~m}$ & Daily & 4 \\
& 20180425 & & & \\
& 20180603 & & & \\
& 20180703 & & & \\
& 20180815 & & & \\
& 20180924 & & & \\
& 20181026 & & & \\
& 20181125 & & & \\
& 20181217 & & & \\
\hline
\end{tabular}

Cloudless images were selected from the months of January to June to ensure that there would be no variances in the data caused by seasonal changes. More details about the imagery collected can be found in Table 2 .

Table 2. Bands available for satellite imagery used

\begin{tabular}{|c|c|}
\hline Satellite & Bands used \\
\hline Landsat 5 & 6 (B, G, R, NIR, SWIR1, SWIR2) \\
Landsat 8 & 6 (B, G, R, NIR, SWIR1, SWIR2) \\
Planetscope & 4 (B, G, R, NIR) \\
\hline
\end{tabular}


Cloudless Planetscope imagery were downloaded for the months of 2018. This excluded images from January, March, and May due to cloud cover. To match the temporal resolution of the monthly tourism influx data of 2018, Planetscope imagery was used since it acquires images daily and it also has a higher spatial resolution of $3 \mathrm{~m}$ (Gasparovic et al., 2018) compared to Landsat's $30-\mathrm{m}$ resolution.

\subsubsection{Tourism}

The data for tourism arrivals was gathered from the Tourism Office of the Municipality of Samboan. The data available spanned 2015 through 2019, with total number of guests provided for each month of the mentioned years.

Tourism data from the year 2018 was then normalized and plotted together with the vegetation index values generated from the 2018 Planetscope imagery.

\subsection{Image Processing}

Thirty reference points were plotted along the Tangbo river line with a 30-m distance between each point, due to the spatial resolution of the imagery being 30 meters.. Sample images from Landsat and Planetscope satellite imagery from the most recent dates used in the study are shown in Figures 2 and 3, respectively.

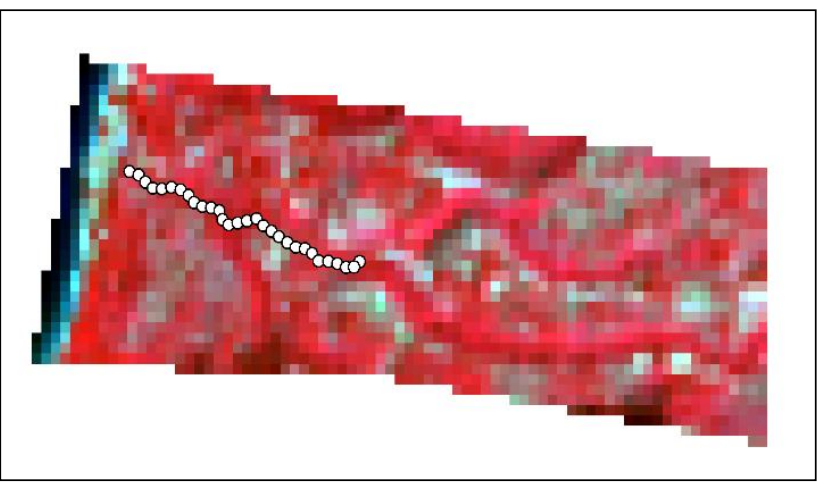

Figure 2. Landsat false-color $(4,3,2)$ composite of Tangbo River, 2019.

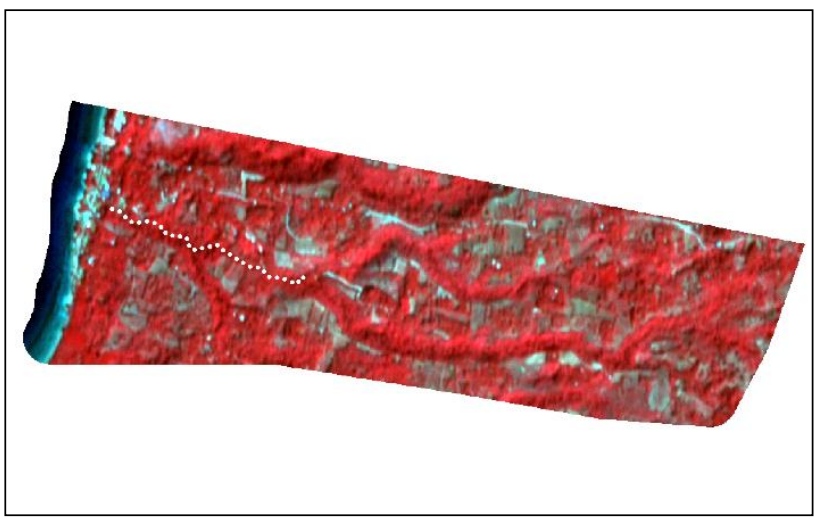

Figure 3. Planetscope false-color $(4,3,2)$ composite of Tangbo River, 2018.

\subsection{Vegetation Indices (VI)}

Three vegetation indices, as well as Tasselled Cap Transformation (TCT) were calculated for the Landsat imagery generated for the years 1998, 2004, 2009, 2016, and 2019. The VI values were extracted from the thirty reference points plotted along Tangbo River.

\subsubsection{Normalized Vegetation Index (NDVI)}

The NDVI is calculated using Near Infrared and Infrared bands. Landsat 5 utilizes band 3 (red) and band 4 (near-infrared) (Masek et al., 2006). Landsat 8 uses band 4 (red) and band 5 (nearinfrared) (Vermote et al., 2016). The NDVI was calculated using the equation below:

$$
N D V I=\frac{N U R-R}{N I R+R}
$$

where NDVI $=$ Normalized Difference Vegetation Index

$$
\begin{aligned}
\text { NIR } & =\text { Near Infrared Band } \\
\mathrm{R} & =\text { Red Band }
\end{aligned}
$$

\subsubsection{Enhanced Vegetation Index (EVI)}

EVI was used as an alternative for some of the limitations of NDVI, since the former corrects distortions made by air particles and the ground. Landsat 5's blue band is band 1 (Masek et al., 2006) and Landsat 8's blue band is band 2 (Vermote et al., 2016). EVI was calculated using the following:

$$
E V I=\frac{(N I R-R)}{N I R+C_{:} \times R-C_{2} \times B+I}
$$

Where NIR $=$ Near Infrared Band

$$
\begin{aligned}
& R=\text { Red Band } \\
& B=\text { Blue band } \\
& L=\text { To adjust for canopy background } \\
& \mathrm{C}=\text { Atmospheric resistance coefficient }
\end{aligned}
$$

\subsubsection{Normalized Difference Moisture Index (NDMI)}

NDMI was used to detect subtle changes in the moisture of the vegetation. The formula for NDMI for Landsat 5 (Masek et al., 2006) and Landsat 8 (Vermote et al., 2016) is shown below:

$$
N D M I=\frac{(N I R-S W I R)}{(N I R+S W I R)}
$$

Where NIR $=$ Near Infrared Band

SWIR $=$ Shortwave Infrared Band

\subsubsection{Tasseled Cap Indices}

TCT was performed on all Landsat 5 and Landsat 8 on the selected imagery. The outputs of the Tasseled Cap transformation are the brightness, greenness, and wetness of the input pixel and can be calculated using the equation below (Devries et al., 2016):

$$
\begin{aligned}
\text { Tass Cap }= & (\text { Coeff } * B)+(\text { Coeff } * G)+(\text { Coeff } * R)+ \\
& (\text { Coeff } * \text { NIR })+(\text { Coeff } * \text { SWIR } 1)+(\text { Coeff } * \text { SWIR } 2)
\end{aligned}
$$

Where Tass. Cap. = Tasseled cap index computed 
Coeff $=$ The coefficients for each band

SWIR1 = Short-wave Infrared 1

SWIR2 = Short-wave Infrared 2

The coefficients for each transformation differs for brightness (b), greenness (g), and wetness (w) and can be found in Table 3.

Table 3. TCT coefficients for surface reflectances

\begin{tabular}{|c|c|c|c|c|c|c|}
\hline & B & G & R & NIR & SWIR & SWIR \\
& & & & & 1 & 2 \\
\hline b & 0.204 & 0.415 & 0.552 & 0.312 & 0.312 & 0.230 \\
$\mathrm{~g}$ & -0.160 & 0.281 & -0.493 & 0.794 & -0.000 & -0.144 \\
$\mathrm{w}$ & 0.031 & 0.202 & 0.310 & 0.159 & -0.680 & -0.610 \\
\hline
\end{tabular}

\subsection{Tourism}

NDVI and EVI values for the year 2018 were generated from Planetscope imagery. The data was then normalized and plotted in order to better understand the patterns between NDVI and EVI in context with tourism. Only the trends in 2018 was plotted due to the availability of the three datasets.

\section{RESULTS AND DISCUSSIONS}

Following the above-mentioned procedures, the values of the vegetation and tasselled cap indices in specific points plotted along the riparian vegetation of Tangbo River were generated for the years 1998, 2004, 2009, 2016 and 2019 respectively. The results can be found in the next section of this paper.

\subsection{Vegetation Indices}

Figure 4 shows the vegetation indices' values in 1998, 2004, 2009, 2016, and 2019 respectively. NDVI values from 1998 to 2019 were found to have an upward trend. The maximum NDVI value was in 2016 at 0.84 , while the lowest was in 1998 at 0.65 . NDVI values close to 1 denote healthy vegetation while values close to 0 means there is sparse or no vegetation present.

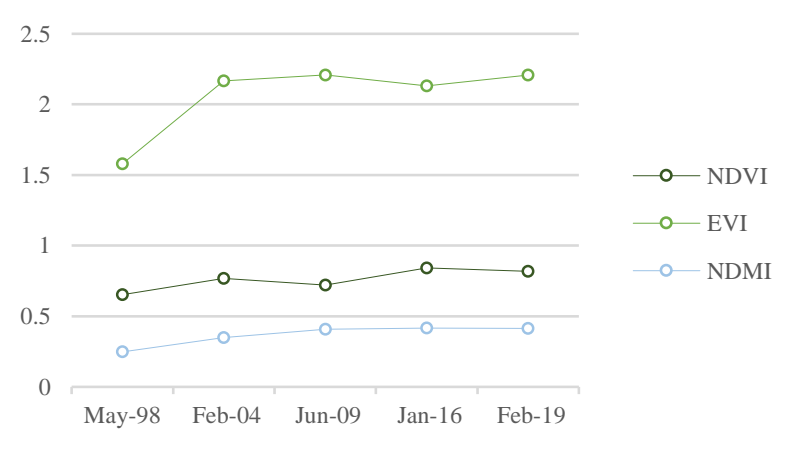

Figure 4. Trends of Vegetation Indices from 1998 to 2019

Likewise, the values of EVI show an increasing trend from 1998 to 2019. The highest EVI value was also in 2016 at 2.1, while the lowest was in 1998 at 1.57 .

The NDMI values also showed an upward trend through time. NDMI values can range from -1 to 1 , with -1 representing no vegetation and 1 as healthy vegetation. The peak NDMI value was in 2016 at 0.42 , while the lowest was in 1998 at 0.24 .

\subsection{Tasseled Cap Indices}

Figure 5 shows the values of Tasseled Cap Transformation from 1998 to 2019 . TCB values were decreasing for the past 21 years.
The peak mean value of TCB was in 1998, at 3110.957, and the lowest value was at 2469.392 in 2004 . TCB values represent the degree of dryness of a certain area.

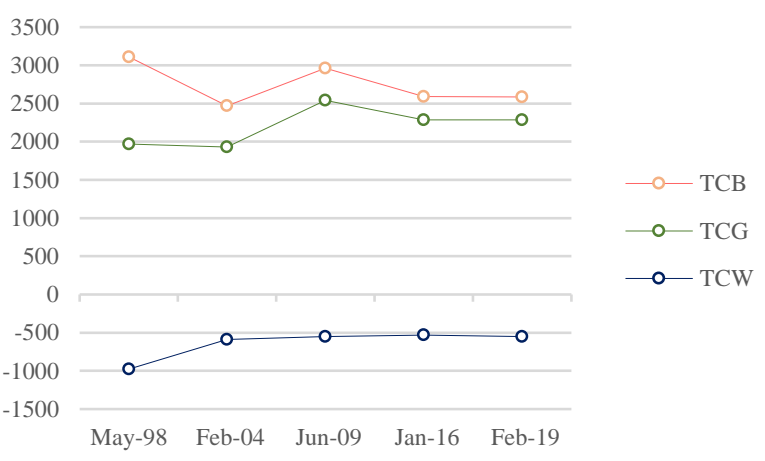

Figure 5. Trends of Tasseled Cap Indices from 1998 to 2019

Greenness values for the past 21 years were also decreasing. The peak mean TCG value was in 2009 at 2541.694, while the lowest was in 2004 at 1930.592 . TCG values represent the greenness of the pixels of the image. A higher degree of greenness denotes more photosynthetically active vegetation (Tasseled-Cap Transformation, 2012).

Finally, TCW values were increasing from 1998 to 2012. Its peak average value was at -531.613 in 2016 , while the lowest value was in 1998 at -977.198 . TCW values denotes the wetness or yellowness of the soil. Higher values represent higher soil or surface moisture content (Tasseled-Cap Transformation, 2012).

\subsection{Tourism influx}

Figure 6 shows the municipal tourism office's record of tourist arrivals in Aguinid Falls. The data was normalized for better visualization. Tourist arrivals' records were collated beginning in 2015. This was when the municipality received a budget for the maintenance of the area (Cacho, 2016). The highest number of arrivals occurred at around May 2015.

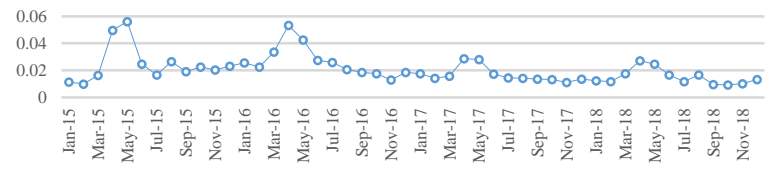

Figure 6. Tourism Percentage in Aguinid Falls, Samboan, Cebu from 2015 to 2019

Notably, they had a high total number of guests in 2016 as well. During this year, Aguinid was awarded as the best ecotourism destination by a local news site, which heightened the interest in the area (Tizon, 2019). Despite an announcement by the government on the decreased water level of the river due to the El Niño phenomenon, it still received a high number of both foreign and local visitors (Gitgano, 2016). The pattern of NDVI, EVI and tourism arrivals is shown in the figure below: 


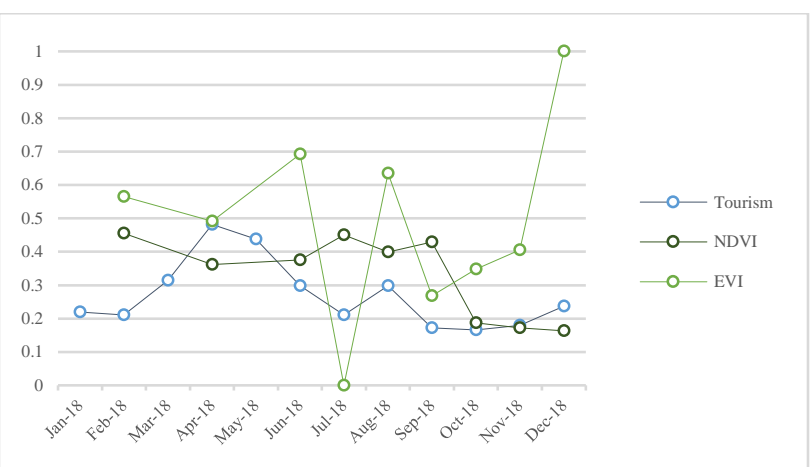

Figure 7. Time Series of Tourist influx vs NDVI and EVI values in 2018

Figure 7 shows a graph of tourism arrivals with NDVI and EVI values plotted together. Only data from 2018 was plotted in this graph because of the availability data from all three variables. The figure shows that Tourism and NDVI are generally decreasing throughout the year, while EVI was generally increasing.

Tourism arrivals hit its peak during April and May of 2018, while arrivals lessened during the second half of the year. NDVI values were lesser during the first half of the year and increased in July to September, coinciding with the decrease in tourist arrivals. EVI values were lowest in July and peaked at the latter part of the year.

Several studies have found that one of the main factors that affect NDVI is climate (Dai et al., 2010). Rainfall and temperature are shown to have an influence on these values. Wet season is from June through November, producing high NDVI and EVI values, while dry season occurs from March to May (Perez and Comiso,2014), which coincides with the data in Figure 7.

According to Figure 6, peak season for tourist arrivals all occur on the same months, which are March to May (dry season). On the other hand, lowest numbers in tourism records occur on the months of September to November (wet season). The rise and fall of VI values and tourism arrivals seemed to be related to the seasonal changes rather than with each other.

\section{LIMITATIONS AND RECOMMENDATIONS}

The data used for vegetation indices consisted of satellite images from the years 1998 to 2019. Only cloudless imagery were selected, which limited the years data collected to the years selected above, as well as from January to June.

The conversion of land for agricultural use and the impact of invasive species on the distribution of riparian vegetation were not considered for this study due to time limitations. Determining the pattern between tourism arrivals and vegetation index values was limited to the year of 2018 since it was only in this year when both datasets were available. The months of March and May was excluded from the tourism data due to the lack of cloudless Planetscope imagery for these two months.

Studying the impact of tourism using changes in vegetation indices is still a relatively unexplored concept. The monitoring of vegetation in natural tourist destinations is important as this sets up a precedent into proper management of natural resources and local government policy declaration. Further data collection is needed to determine a definite relationship between tourism arrivals and its effect on the values of vegetation indices. As such, the limitations of this study may be used as factors in future research.

\section{CONCLUSIONS}

This study monitored changes in vegetation indices and tasseled cap values. In 21 years, vegetation indices have generally shown an increase in value, with tasseled cap brightness and greenness showing the same trend. This imply that riparian vegetation along the river from 1998 to 2019 increased.

Tourism arrivals also showed a steady increase around March to May from 2015 to 2018. However, the vegetation indices in 2018 decreased from the months March to May as well, which falls under the dry season and increased at the latter part of the year which is at the same time as the wet season. This suggests that vegetation indices and tourism arrivals are heavily influenced by seasonal changes rather than with each other.

\section{ACKNOWLEDGEMENTS}

We are grateful to the Department of Science and Technology (DOST) for the financial support, with the DOST Philippine Council for Industry, Energy and Emerging Technology Research and Development (PCIEERD) as the monitoring agency and the University of the Philippines Cebu as the implementing agency.

Additionally, the author would like to give special thanks to the Municipality of Samboan for providing data and information on tourism and in answering our queries.

\section{REFERENCES}

Alampay, R., 2005. The Challenge of Sustainable Tourism Development in the Philippines. Makati: Philippine Apec Study Center Philippines, pp. 1-22. https://www.researchgate.net/ publication/306257124_The_Challenge_of_Sustainable_Touris m_Development_in_the_Philippines. September 11, 2019.

Baig, M., Zhang, L., Shuai, T. \& Tong, Q., 2014. Derivation of a tasselled cap transformation based on Landsat 8 at-satellite reflectance. Remote Sensing Letters, 5(5), 423 - 431. DOI:10.1080/2150704X.2014.915434.

Buslon-Sia, V., Ferrater-Gimena, J., Etcuban, J., Tan, A. Ecotourism as a Catalyst of Poverty Alleviation in Rural Economy in Cebu, Philippines. Asian Review of Social Sciences, 8(3), 1-7. Retrieved from http://www.trp.org.in

Cacho, K., 2016. Ecotourism theme park. Sunstar Philippines. https://www.sunstar.com.ph/article/95207. September 12, 2019.

Devries, B., Pratihast, A., Verbesselt, J., Kooistra, L., Herold, M., 2016. Characterizing Forest Change Using Community-Based Monitoring Data and Landsat Time Series. PLoS ONE, 11(3), e0147121. DOI: 10.1371/journal.pone.0147121.

Dai, S., Zhang, B., Wang, H, 2010. Spatio-temporal change of vegetation index NDVI in Northwest China and its Influencing Factors. Journal of Geo-Information Science, 03. en.cnki.com.cn/Article_en/CJFDTotal-DQXX201003003.htm. September 14, 2019.

Dosskey, M., Vidon, P., Gurwick, N., Allan, C., Duval, T., Lowrance, R, 2010; The Role of Riparian Vegetation in 
Protecting and Improving Chemical Water Quality in Streams. Journal of the American Water Resources Association, 1-18. DOI: $10.1111 / \mathrm{j} .1752-1688.2010 .00419 . x$.

Fennell, D, 2003. Ecotourism and Ecotourists. Ecotourism: An Introduction, pp. 18-20. books.google.com.ph /books?id=VAY Yfo0gCpQC\&pg=PA18\&source=gbs_toc_r\&cad=4\#v=onepage $\& \mathrm{q} \& \mathrm{f}=$ false. September 5, 2019.

Gaither, M., Rocha, L. (2013). Origins of species richness in the Indo-Malay-Philippine biodiversity hostpot: evidence for the centre of overlap hypothesis. Journal of Biogeography, 40(9). DOI: $10.1111 /$ jbi.12126

Gamallo, I, 2019, July 3. Personal Interview.

Gamallo, I, 2019, September 13. Phone interview.

Gasparovic, M., Medak, D., Pilas, I., Jurjevic, L., 2018. Fusion of Sentinel-2 and Planetscope Imagery for Vegetation Detection and Monitoring. International Archives of the Photogrammetry, Remote Sensing and Spatial Information Sciences, XLII-1. DOI: 10.5194/isprs-archives-XLII-1-155-2018.

Gitgano, F., 2016. More tourists still visit Aguinid. Sunstar Philippines. sunstar.com.ph/article/64535. September 12, 2019.

Honey, M., 2008. In Search of the Golden Toad. Ecotourism and Sustainable Development: Who Owns Paradise? 3-33. books.google.com.ph/books?hl=en\&lr=\&id =Jw2hy_2E5nwC \&oi=fnd\&pg=PR5\&dq=ecotourism\&ots=8qnUeSa9ya\&sig=Yy 7jn-EltRPQ21Qt7ZhFvVTC7Ws\&redir_esc=y . September 5, 2019.

Jafari, R., Lewis, M., Ostendorf, B., 2007. Evaluation of vegetation indices for assessing vegetation cover in southern arid lands in South Australia. The Rangeland Journal, (29)1. DOI: 10.1071/1/RJ06033.

Ji, L., Peters, A., 2007. Performance evaluation of spectral vegetation indices using a statistical sensitivity function. Remote Sensing of Environment, 106(2007), 59-65. DOI: 10.106/j.rse.2006.07.010

Kiper, T., 2013. Role of Ecotourism in Sustainable Development. Advances in Landscape Architecture. DOI: 10.5772/55749.

Liu, Y., Li, Y., Li, s., Motesharrei, S., 2015. Spatial and Temporal Patterns of Global NDVI Trends: Correlations with Climate and Human Factors. Remote Sens, 7(10), 13233-13250. DOI: $10.3390 /$ rs 71013233 .

Lorion, C., \& Kennedy, B., 2009; Relationships between deforestation, riparian forest buffers and benthic macroinvertebrates in neotropical headwater streams. Freshwater Biology, 54, 165-180. DOI:10.1111/j.13652427.2008.02092.x

Masek, J.G., Vermote, E.F., Saleous, N., Wolfe, R., Hall, F.G., Huemmrich, F., Gao, F., Kutler, J., and Lim, T.K., 2006. A Landsat surface reflectance data set for North America, 1990100, IEEE Geoscience and Remote Sensing Letters. 3:68-72.

Mittermeier, R., Robles-Gil, P., Mittermeier, C. G., 1997. Earth's biologically wealthiest Nations. Megadiversity. Mexico City: CEMEX/Agrupaciaon Sierra Madre.
NASA, 2000. Normalized Difference Vegetation Index (NDVI). earthobservatory.nasa.gov/features/MeasuringVegetation/measu ring_vegetation_2.php. September 12, 2019.

Null, J., 2019. El Niño and La Niña Years and Intensities. Golden Gate Weather Services. ggweather.com /enso/oni.htm. September 15, 2019.

Patel, N., Saha, S., Dadhwal, V., 2007. Investigating the vegetation and agricultural responses to $\mathrm{El}$ Nino/Southern Oscillation using AVHRR data. Geocarto International, 22(4), 237-249. DOI: 10.1080/10106040701204289

Perez, G., Comiso, J, 2014. Seasonal and Interannual Variables of Philippine Vegetation as Seen from Space. Philippine Journal of Science, 143(2): 147-155.

Perez, G., Macapagal, M., Olivares, R., Macapagal, E., Comiso, J., 2016. Forecasting and Monitoring Agricultural Drought in the Philippines. The International Archives of Photogrammetry, Remote Sensing and Spatial Information Sciences, XLI-B8.

Sajadi, S., 2011. A relationship between NDVI and tasseled cap techniques. Geospatial World. geospatialworld.net/article/arelationship-between-ndvi-and-tasseled-cap-techniques /\#targetText=Tasseled\%20cap $\% 20$ is\% 20another\%20index, values\%20and\%20high\%20brightness\%20values. September $14,2019$.

Scalley, T., and Aide, T., 2003; Riparian Vegetation and Stream Condition in a Tropical Agriculture-Secondary Forest Mosaic. Ecological Applications, 13(1), 225-234.

Stella, J. C., \& Bendix, J., 2019; Multiple Stressors in Riparian Ecosystems. Multiple Stressors in River Ecosystems, 81-110. DOI: 10.1016/b978-0-12-811713-2.00005-4.

Tasseled-Cap Transformation, 2012, March 8. The Landscape Toolbox,https://wiki.landscapetoolbox.org/doku.php/remote_se nsing_methods:tasseled-cap_transformation

Tizon, M., 2019. Famous falls in Samboan, Cebu, close for a month for rehab. Rappler. rappler.com/nation/232 290-aguinidfalls-samboan-cebu-close-for-rehabilitation-june-2019. September 12, 2019.

Toribio, M., Hernandez, I., Manriquez, G., 2014; Effect of land use on the structure and diversity of riparian vegetation in the Duero river watershed in Michoacan, Mexico. Plant Ecology, 215(3), 285-296.

Vermote, E., Justice, C., Claverie, M., and Franch, B., 2016. Preliminary analysis of the performance of the Landsat 8/OLI land surface reflectance product. Remote Sensing of Environment, 185, 46-56.

Xue, J., Su, B., 2017. Significant Remote Sensing Vegetation Indices: A Review of Developments and Applications. Journal of Sensors. DOI: 10.1155/2017/1353691.

Yang, C., 2019. Boracay closure was 'blessing in disguise' says Tourism chief. ABS-CBN News. news.abscbn.com/business/06/28/19/boracay-closure-was-blessing-indisguise-says-tourism-chief. September 14, 2019 